\title{
CTTN Gene
}

National Cancer Institute

\section{Source}

National Cancer Institute. CTTN Gene. NCI Thesaurus. Code C18382.

This gene plays a role in epithelial cytoskeletal org anization and in cellular adhesion. 